\title{
DISZKRÉT KOCKÁZATI MODELL ÁLTALÁNOS BEFIZETÉSI RÁTA MELLETT
}

\author{
GYŐRFI-BÁTORI ANDRÁS, MIHÁLYKÓ CSABA, MIHÁLYKÓNÉ ORBÁN ÉVA
}

\begin{abstract}
A publikációban egy Sparre Andersen-kockázati folyamatot vizsgálunk. Egy diszkrét modellel foglalkozunk, amelyben általános befizetési rátát feltételezünk. A Gerber-Shiu-függvény egy diszkrét változatára általános esetben differenciaegyenletet adunk meg, a differenciaegyenlet megoldásának egyértelmüségére feltételt adunk. Az egyenletet negatív binomiális káreloszlás esetén egy másik egyenletté transzformáljuk, amelynek megadjuk a megoldását. Eredményünket példával illusztráljuk.
\end{abstract}

\section{Bevezetés}

Az üzleti életben működő vállalatoknak, így a biztosítótársaságoknak is fontos, hogy üzleti környezetükből fakadó kockázataik felismerhetőek és kezelhetőek legyenek, ne veszélyeztessék müködésüket. A biztosítók kockázata az általuk kínált szolgáltatás sztochasztikus természetén alapszik. Ezen kockázatok felmérése mind a biztosítótársaságok szempontjából, mind pedig a velük szerződést kötött ügyfelek számára fontos, hiszen nekik sem érdekük, hogy a társaság fizetésképtelenné váljon. Hasonló kérdések vetődnek fel ipari rendszereknél közbülső tárolók alkalmazása esetén is (lásd például [7]).

A kockázati folyamatok vizsgálata a huszadik század elején kezdett intenzíven fejlődni. Kezdőpontként Lundberg munkáját érdemes említeni 1903-ból. Később, 1957-től, nagyrészt az úgynevezett Sparre Andersen-modellt használták, amelyben a kárigények között eltelt idő eloszlását exponenciális eloszlás helyett általánosnak tekintették. Folytonos eloszlások esetén nagy áttörést hozott a Gerber-Shiu-féle diszkontált büntetőfüggvény [3] bevezetése, mivel így egyetlen függvény segítségével lehet számolni a tönkremenés valószínüségét és a tönkremenési idő várható értékét, sőt a tönkremenés idejének szórását is. A Gerber-Shiu-függvény matematikai tulajdonságainak elemzésével, speciális esetekben kiszámolásával számos publikáció foglalkozik ([3], [1], [8], [9]).

A diszkrét kockázati modellekre kevesebb figyelem jut, mint a folytonosakra, bár gyakorlati szempontból nagyobb a jelentőségük. Az irodalomban megtalálható publikációk többnyire egységnyi befizetési rátát feltételeznek, és a kárigények ennek többszöröseit teszik ki. A Gerber-Shiu-függvény diszkrét megfelelőjét 
Cheng és társai írták fel 2000-ben [2]. Számos speciális esetben található eredmény vele kapcsolatban [6]-ban és az ott hivatkozott cikkekben. Li [5]-ben olyan esettel foglalkozott, amikor a károk között eltelt idő véletlen nagyságú. Ekkor a szerző rekurziót adott meg a Gerber-Shiu-függvényre. A folytonos esetben Albrecher és munkatársai adtak kváziexplicit megoldást 2010-ben olyan feltételezések mellett, hogy a károk között eltelt idő és a károk nagysága eloszlása sürüségfüggvényének Laplace-transzformáltja racionális törtfüggvény. Megjegyezzük, hogy az irodalomban megtalálható publikációk nem foglalkoznak a felírt differencia/differenciálegyenlet megoldásának egyértelmüségével, csupán adnak egy megoldást. Ezzel kapcsolatban elvi problémát jelent, hogy az egyenleteknek számos esetben nem egyértelmű a megoldása, így a megtalált megoldás nem biztos, hogy a keresett függvénnyel azonos.

Jelen cikkben általánosítjuk Li eredményeit Albrecher és társai által vizsgált irányban haladva. Általános károk közti időeloszlást és kárigényeloszlást alkalmazva vizsgáljuk a Gerber-Shiu-függvény egy speciális esetére felírt egyenlet egyértelmü megoldhatóságát, és negatív binomiális eloszlású kárigények esetén megadjuk a függvényt. A vizsgált modell annyiban is általánosabb a szokásosnál, hogy nem tételezzük fel, hogy a kárigények a befizetési ráta egész számú többszörösei. Eredményünket egy példán illusztráljuk.

\section{A vizsgált modell}

Vizsgáljuk a biztosítótársaság kasszájában levő pénzösszeget az idő függvényében. A biztosítótársasághoz időegységenként beérkező pénzmennyiséget jelölje $k \in \mathbb{N}^{+}$, a kezdőtőkéjét pedig $n \in \mathbb{N}$. Legyen $V(t)$ a biztosítótársaság kasszájában lévő pénzmennyiség a $t$. időpillanatban, ahol $t$ nemnegatív egész szám. Jelölje $N(t)$ a bekövetkező károk számát a $t$. időpillanatig, és legyen $Z_{l}$ a biztosítótársasághoz beérkező $l$. kárigény nagysága. Mindkettő véletlen mennyiség, és tegyük fel, hogy egymástól is függetlenek, valamint a $Z_{l}, l=1,2, \ldots$ valószínüségi változók nemnegatív, egész értéküek és azonos eloszlásúak. Ekkor $t$ idő eltelte után a társaság pénzmennyisége az alábbi:

$$
V(t)=n+k \cdot t-\sum_{l=1}^{N(t)} Z_{l}, t=0,1, \ldots
$$

Jelölje $u(n)$ annak a valószínüségét, hogy $n$ kezdőtőkéről indulva a biztosítótársaság csődbemegy, azaz a tőkéje 0 alá csökken:

$$
u(n)=P\left(n+k \cdot t-\sum_{l=1}^{N(t)} Z_{l}<0, \text { valamely } t=0,1,2, \ldots \text { esetén }\right) .
$$

Negatív $n$ érték esetén értelemszerüen $u(n)=1$. 
Legyen $T_{V}(n)$ a tönkremenési idő $n$ kezdőtőke esetén, amennyiben tönkremegy a biztosítótársaság, azaz

$$
T_{V}(n)=\left\{\begin{array}{c}
\min \{t \geq 0: t \in \mathbb{N}\}, V(t)<0, \\
\infty, \text { ha } V(t) \geq 0, \quad \forall t \in \mathbb{N} .
\end{array}\right.
$$

Legyen

$$
\begin{gathered}
E T(n)=E\left(T_{V}(n) \cdot 1_{\left(T_{V}(n)<\infty\right)}\right), \\
D^{2} T(n)=E\left(T_{V}^{2}(n) \cdot 1_{\left(T_{V}(n)<\infty\right)}\right)-E^{2}\left(T_{V}(n) \cdot 1_{\left(T_{V}(n)<\infty\right)}\right),
\end{gathered}
$$

feltéve, hogy a várható érték és a szórásnégyzet véges. Vezessük be továbbá a Gerber-Shiu-féle diszkontált függvény diszkrét verzióját abban a speciális esetben, amikor a Gerber-Shiu-függvény nem függ a csőd nagyságától és a csőd bekövetkezése előtt felhalmozott tőke értékétől:

$$
\varphi(n, z)=E\left(z^{-T_{V}(n)} \cdot 1_{\left(T_{V}(n)<\infty\right)}\right), z \geq 1 .
$$

Látható, hogy $\varphi(n, z)$ minden $n \in \mathbb{N}$ és $z \geq 1$ esetén 0 és 1 közé esik, azaz $\varphi(n, z)$ jól definiált. Látható, hogy $n<0$ esetén $\varphi(n, z)=1$. Minden rögzített $z$ esetén $n$-ben és rögzített $n$ esetén $z$-ben monoton fogy. Továbbá fennáll, hogy

$$
\begin{gathered}
\varphi(n, 1)=u(n), \quad \operatorname{ET}(n)=-\left.\frac{\partial \varphi(n, z)}{\partial z}\right|_{z=1}, \\
D^{2} T(n)=\left.\frac{\partial^{2} \varphi(n, z)}{\partial^{2} z}\right|_{z=1}-E T(n)-(E T(n))^{2} .
\end{gathered}
$$

Legyen $t_{0}=0$, és jelölje az $(l-1)$. és az $l$. kárigény között eltelt időt $t_{l}$, $l=1,2,3, \ldots \mathrm{A} t_{l}$ valószínüségi változókról feltételezzük, hogy egymástól és a $Z_{l}$ valószínüségi változóktól is függetlenek és azonos eloszlásúak. A károk között eltelt idő eloszlását jelölje $f(j)=P\left(t_{l}=j\right), j=0,1, \ldots$, míg a károk nagyságának eloszlását $g(i)=P\left(Z_{l}=i\right), i=1,2, \ldots$ A $t_{l}$ lehetséges értékeinél megengedjük a $j=0$ értéket, de a károk nagysága csak pozitív egész szám lehet. Az irodalomban vizsgált eseteknél ez többszöröse az egységnyi idő alatt befizetett pénzmennyiségnek, mi most annak törtrészét is megengedjük. Mind a $t_{l}$, mind a $Z_{l}$ valószínüségi változók esetén véges szórást feltételezünk.

A folyamat viselkedését alapvetően befolyásolja, hogy az egységnyi idő alatt befizetett és a kifizetett pénzösszeg várható értéke hogy viszonyul egymáshoz. Az

$$
E\left(Z_{l}\right)<k \cdot E\left(t_{l}\right)
$$

egyenlőtlenség azt fejezi ki, hogy a befizetett pénzmennyiség várható értéke több a kifizetettnél, ezt nettó profit feltételnek nevezik. A nagy számok erős törvénye és a Chung-Fuchs-tétel alkalmazásával belátható, hogy

$$
\lim _{n \rightarrow \infty} u(n)=0 \text {, ha } E\left(Z_{l}\right)<k \cdot E\left(t_{l}\right),
$$




$$
u(n)=1 \quad \forall n \geq 0 \text {, ha } k \cdot E\left(t_{l}\right) \leq E\left(Z_{l}\right) .
$$

\section{A $\varphi(n, z)$-re vonatkozó összefüggések}

Az első kárkifizetés időpontja és a kárkifizetés nagysága szerinti feltételes várható érték alkalmazásával (2)-re az alábbi egyenlet írható fel:

$$
\varphi(n, z)=\sum_{j=0}^{\infty} \sum_{i=1}^{n+j k} \varphi(n+j k-i, z) f(j) g(i) z^{-j}+\sum_{j=0}^{\infty} \sum_{i=n+j k+1}^{\infty} f(j) g(i) z^{-j},
$$

ezért (3), (4) miatt az

$$
X(n, z)=\sum_{j=0}^{\infty} \sum_{i=1}^{n+j k} X(n+j k-i, z) f(j) g(i) z^{-j}+\sum_{j=0}^{\infty} \sum_{i=n+j k+1}^{\infty} f(j) g(i) z^{-j}
$$

egyenlet megoldására vagyunk kíváncsiak. A (7) egyenlet megoldása azonban általánosan nem egyértelmü. Például $z=1$ esetén a konstans 1 sorozat kielégíti az egyenletet. Mi a korlátos, sőt a 0-hoz tartó megoldásokat keressük. Ezzel kapcsolatban az alábbi állítás bizonyítható a kontrakciós elv segítségével:

3.1. TÉtel. Ha $f(0)<1$, akkor minden $1<z$ esetén $(7)$-nek pontosan egy megoldása van a korlátos sorozatok körében. Ha $z=1$, akkor (5) teljesülése esetén a (7) egyenletnek pontosan egy megoldása van a nullához tartó sorozatok körében.

3.1. KÖvetKezmÉNy. Ha $1<z$, akkor $f(0)<1$ esetén $(7)$ korlátos megoldása a (2) által definált $\varphi(n, z)$ függvény, míg $z=1$ esetén, ha a nettó profit feltétel teljesül, akkor az egyetlen zéróhoz konvergáló megoldása az (1) által definiált $u(n)$.

Ezek alapján a (7) differenciaegyenlet ilyen megoldásait keressük.

Az alapegyenlet általános megoldása nem ismert. A számos vizsgált speciális eset közül (lásd [4]) tekintsük most a negatív binomiális eloszlások esetét. Ekkor az alábbi állítás bizonyítható ([4]):

3.2. TÉTEL. Legyen a károk közt eltelt idők eloszlása általános, míg a kárigények eloszlása (eggyel eltolt) negatív binomiális eloszlás a $2 \leq s$ és $0<q<1$ paraméterrel, azaz

$$
g(i)=\left(\begin{array}{c}
i+s-2 \\
s-1
\end{array}\right) q^{i-1}(1-q)^{s}, i=1,2, \ldots
$$

Ekkor (6) az alábbi alakba transzformálható:

$$
\varphi(n, z)=\sum_{r=1}^{s}\left(\begin{array}{l}
s \\
r
\end{array}\right) q^{r} \cdot(-1)^{r+1} \varphi(n-r, z)+(1-q)^{s} \sum_{j=0}^{\infty} \varphi(n-1+k j, z) \cdot f(j) \cdot z^{-j} .
$$


A Rouché-tétel segítségével belátható, hogy a (8) egyenlet karakterisztikus egyenletének $1<z$ esetén pontosan $s$ darab egynél kisebb abszolút értékü gyöke van, míg $z=1$ esetén legfeljebb $s$ az abszolút értékben egynél kisebb gyökök száma. A gyökök ismeretében $\varphi(n, z)$ felírható a szokásos módon, speciálisan egyszeres gyökök esetén ezek $n$-edik hatványai lineáris kombinációjaként. A gyököket $\mu_{i}(z)$-vel jelölve ekkor a $c_{i}(z)$ együtthatókra az alábbi összefüggések teljesülnek $(l=1,2, \ldots, s)$ :

$$
c_{1}(z) \frac{\mu_{1}^{l-1}(z)}{\left(\mu_{1}(z)-q\right)^{l}}+c_{2}(z) \frac{\mu_{2}^{l-1}(z)}{\left(\mu_{2}(z)-q\right)^{l}}+\ldots+c_{s}(z) \frac{\mu_{s}^{l-1}(z)}{\left(\mu_{s}(z)-q\right)^{l}}=\left(\frac{1}{1-q}\right)^{l} \text {. }
$$

Ez egyértelműen megoldható, és megoldásával megkaphatjuk $\varphi(n, z)$-t.

\section{Alkalmazás}

Egy biztosítótársasághoz naponta érkezik 3 millió forint bevétel a biztosított felektől. Tételezzük fel, hogy az előző kárigényhez viszonyítva 0,35 valószínüséggel aznap, 0,25 valószínüséggel a következő nap, 0,4 valószínüséggel 2 nap múlva érkezik legközelebb kárigény. Tegyük fel, hogy a károk nagysága negatív binomiális eloszlású $s=2$ paraméterrel, és átlagosan naponta 2,5 millió forintot kell kifizetni. Válasszuk időegységnek az 1 napot, pénzegységnek az 1 millió Ft-ot.

Jelen példában $k=3, f(0)=0,35, f(1)=0,25, f(2)=0,4$. Felhasználva a negatív binomiális eloszlás várható értékének képletét, $q=0,4286$.

A $\varphi(n, z)$-re vonatkozó egyenlet az alábbi:

$$
\begin{aligned}
& \varphi(n, z)=2 q \varphi(n-1, z)-q^{2} \varphi(n-2, z)+ \\
& (1-q)^{2} \cdot\left(\varphi(n-1, z) \cdot 0,35+\varphi(n+2, z) \cdot 0,25 \cdot z^{-1}+\varphi(n+5, z) \cdot 0,4 \cdot z^{-2}\right) .
\end{aligned}
$$

(10) karakterisztikus egyenlete

$$
0,1306 \mu(z)^{7}+0,0816 \mu(z)^{4} \cdot z-\mu(z)^{2} \cdot z^{2}+0,9715 \mu(z) \cdot z^{2}-0,1837 \cdot z^{2}=0 .
$$

Ennek $z=1$ esetén két megfelelö gyöke a $\mu_{1}=-0,2564$ és $\mu_{2}=0,7315$, a hozzájuk tartozó konstansok (9) alapján $c_{1}=-0,0185$ és $c_{2}=0,7315$. Tehát

$$
\varphi(n, 1)=u(n)=c_{1} \cdot \mu_{1}^{n}+c_{2} \cdot \mu_{2}^{n}=-0,0185 \cdot(-0,2564)^{n}+0,7315 \cdot 0,7315^{n} .
$$

\section{Köszönetnyilvánítás}

A kutatást részben az EMMI ÚNPK-16-1-1. számú Új Nemzeti Kiválóság Programja, részben a VKSZ_12-1-2013-0088 Felhő alapú intelligens informatikai szolgáltatások kialakítása az IBM Magyarországi Kft. és a Pannon Egyetem együttmüködésében címü projekt támogatta. A támogatásokat a szerzők köszönik. 


\section{Hivatkozások}

[1] Albrecher, H., Constantinescu, C., Pirsic, G., Regensburger, G., and RosENKRANZ, M.: An algebraic operator approach to the analysis of Gerber-Shiu functions, Insurance: Mathematics and Economics, Vol. 46 No. 1, pp. 42-51 (2010). DOI: 10.1016/j.insmatheco.2009.02.002

[2] Cheng, S., Gerber, H. U., And Shiu, E. S.: Discounted probabilities and ruin theory in the compound binomial model, Insurance: Mathematics and Economics, Vol. 26 No. 2 , pp. 239-250 (2000). DOI: 10.1016/S0167-6687(99)00053-0

[3] Gerber, H. U. And Shiu, E. S.: On the time value of ruin, North American Actuarial Journal, Vol. 2 No. 1, pp. 48-72 (1998). DOI: 10.1080/10920277.1998.10595671

[4] Győrfi-Bátori, A.: Diszkrét kockázati folyamatok matematikai és számítógépes elemzése alkalmazásokkal, PE-MIK OTDK dolgozat,

URL: https://drive.google.com/open?id=0B8Fej12XGLu1VUh2Nmp0S2NjN2M (2017).

[5] LI, S.: On a class of discrete time renewal risk models, Scandinavian Actuarial Journal, Vol. 2005 No. 4, pp. 241-260 (2005). DOI: 10.1080/03461230510009745

[6] Li, S., Lu, Y., AND Garrido, J.: A review of discrete-time risk models, RACSAM-Revista de la Real Academia de Ciencias Exactas, Fisicas y Naturales. Serie A. Matematicas, Vol. 103 No. 2, pp. 321-337 (2009). DOI: 10.1007/978-90-313-7627-8_103

[7] Minálykó, C. And Orbán-Minálykó, É.: Sizing Intermediate Storages in Discrete Models under Stochastic Operational Conditions, Periodica Polytechnica Chemical Engineering, Vol. 60 No. 3, pp. 192-200 (2016). DOI: 10.1016/j.repl.2016.06.044

[8] MiнÁLyKó, É. O. AND MinÁLYKó, C.: Mathematical investigation of the Gerber-Shiu function in the case of dependent inter-claim time and claim size, Insurance: Mathematics and Economics, Vol. 48 No. 3, pp. 378-383 (2011). DOI: 10.1016/j.insmatheco.2011.01.005

[9] Orbán-MinÁlykó, É. AND Minálykó, C.: Necessary and sufficient condition for the boundedness of the Gerber-Shiu function in dependent Sparre Andersen model, Miskolc Mathematical Notes, Vol. 15 No. 1, pp. 159-170 (2014).

DOI: $10.1215 / 9780822399674-007$ 


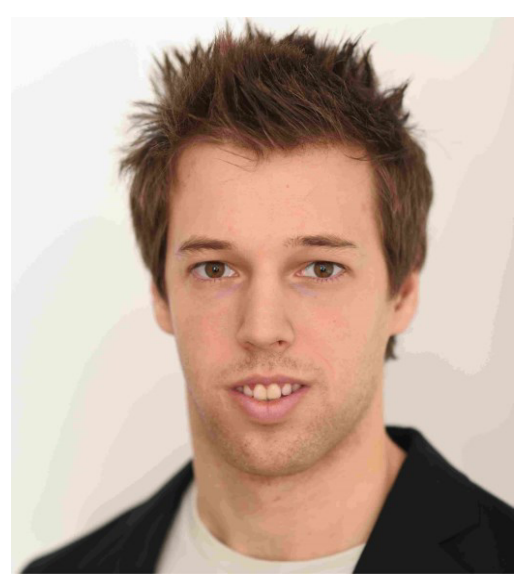

Győrfi-Bátori András 1995-ben született Kaposváron. Egyetemi tanulmányai során az alapképzést a Pannon Egyetem Müszaki Informatikai Karán végezte mérnökinformatikus szakon, majd a mesterképzést a Budapesti Müszaki és Gazdaságtudományi Egyetem Villamosmérnöki Karán végezte szintén mérnökinformatikus szakon, kitüntetéses diplomával. A matematikát már az általános iskolában és gimnáziumban is versenyszerüen üzte, és több országos versenyen is kiemelkedő eredményeket ért el. Az egyetemen ugyan az informatikai szakot választotta, de a matematikaversenyeket, és a matematikában való kutatást nem hagyta abba, így jutott el odáig, hogy az Országos Tudományos Diákköri Konferencián egy matematikai és informatikai témában első helyet szerezzen. Az egyetem végeztével az Interticket Kft.-nél helyezkedett el programozó és matematikai modellező szakemberként.

\section{GYŐRFI-BÁTORI ANDRÁS}

Pannon Egyetem

Matematika Tanszék

8200 Veszprém, Egyetem u. 10.

gyorfi.batori.andras@gmail.com

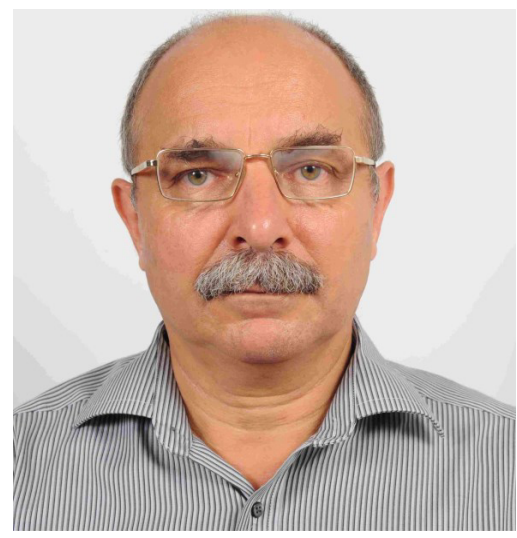

Dr. Mihálykó Csaba 1962-ben született Veszprémben. 1987-ben szerzett az Eötvös Loránd Tudományegyetemen okleveles matematikus végzettséget, majd 1996-ban alkalmazott matematika területén $\mathrm{PhD}$-t ugyanott. 1994ben Farkas Gyula-emlékdíjat, 2000-ben Bolyai János Kutatási Ösztöndíjat, 2019-ben Mestertanár Aranyérmet kapott. 1987 óta dolgozik Veszprémben a Pannon Egyetemen, illetve jogelödjein, jelenleg a Matematika Tanszéken egyetemi docensként. Kutatási területei: kockázati folyamatok, döntéselmélet, matematikai modellezés. Eddig több mint 135 tudományos közleménye jelent meg, ezek közül 51 tudományos folyóiratban. Összes független hivatkozásainak száma meghaladja a 220-at, Hirsch-indexe 8.

\section{MIHÁLYKÓ CSABA}

Pannon Egyetem

Matematika Tanszék

8200 Veszprém, Egyetem u. 10.

mihalyko@almos.uni-pannon.hu 
Mihálykóné Orbán Éva arcképe és életrajza a szám egy másik cikkénél jelenik meg, mely cikknek szintén szerzője.

\section{ORBÁN-MIHÁLYKÓ ÉVA}

Pannon Egyetem

Matematika Tanszék

8200 Veszprém, Egyetem u. 10.

orbane@almos.uni-pannon.hu

\section{A DISCRETE SPARRE ANDERSEN RISK MODEL WITH GENERAL INCOME RATE}

\section{András Győrfi-BÁtori, Csaba Mihálykó, Éva Orbán-Mihálykó}

A discrete Sparre Andersen risk process with general income rate is investigated. A discrete version of the Gerber-Shiu function is introduced and a difference equation is set up for it. The existence and the uniqueness of its solution is investigated and an analytical solution is given in the case when the claim size has negative binomial distribution. An example is given for illustrating the computations.

Keywords: risk process, discrete model, negative binomial claim size distribution, analytical solution.

Mathematics Subject Classification (2000): 91B30, 39A60. 